\title{
oReport
}

\section{Sharing the experiences on the implementation of environmental horticulture in Indonesia}

\section{Bambang Sulistyantara}

Department of Landscape Architecture, Faculty of Agriculture, Bogor Agricultural University, Indonesia

Email: bbsulistyantara@yahoo.co.id

\begin{abstract}
This article touches upon the current activities of applied Environmental Horticulture in Bogor Agricultural University, Indonesia. Activities are Agro-Education Tourism (AET) and Integrated Plant Clinic Car Program. IPB operates two major services to support profession development of landscape architects who graduated from IPB. Services are Public Consultation service and Expertise Certification Service.
\end{abstract}

\section{Introduction}

Graduated from doctoral program at Chiba University in 1997, Bambang Sulistyantara is a faculty member of Faculty of Agriculture, Bogor Agricultural University Indonesia and briefly explains his experiences in his own country. With the background of a landscape architect and planner, in this paper he describes his experiences in the field of environmental horticulture.

I am very happy to have a chance for us to meet together in this symposium. Of course this is with a hope that the ideal purposes stated in the first symposium last year can be realized. The purpose of the symposium contains great expectation for scientific development and application of technology within the scope of environmental horticulture in wide understanding.



Figure 1. View of laboratory of Urban Landscape Design at Faculty of Horticulture, Chiba University
Educational background

My first chance to attend Chiba University started from the master's program in 1991 and continued to the doctoral program in 1994. I graduated both programs at The Laboratory of Urban Environmental Design (Toshi Kankyou Dezain), beginning with the guidance of Prof. Sadatoshi Tabata and continuing in the guidance of Prof. Yoritaka Tashiro. I finished the doctoral program in March 1997.

I am very grateful to all the supervisors who gave me opportunities and directed me to get the education at the Chiba University. I also thank all the teachers involved in the process of my education.

In the next section, I describe several experiences that illustrates the implementation and development of science and technology related to the scope of environmental horticulture in my own country.



Figure 2. View of Faculty of Agriculture, Bogor Agricultural University (IPB), Indonesia 


\section{Current position}

Since completing the education program at Chiba University, I immediately returned to duty as lecturer and faculty staff at the Faculty of Agriculture, Bogor Agricultural University (IPB). In particular, today I teach at the Department of Landscape Architecture, Faculty of Agriculture, Bogor Agricultural University. The Department of Landscape Architecture at Bogor Agricultural University is the largest of its kind in Indonesia, and was the first (since 1999) to offer a Graduate Program of Landscape Architecture leading to a Master's Degree.

As faculty staff, I arrange the time to perform cooperative activities with other relevant institutions, those are the Jakarta City Park and Cemetery Office and the Ministry of Public Works. In the Jakarta Park and Cemetery Office I share the time for the membership of Advisory Board within it. The task of this section is to assist the Head Office in arranging the annual activity program for development plan and evaluation system of parks in Jakarta. Included in this duty is to evaluate landscape site design competitions, which the advisory board gives approval before construction begins.

Part of my activities also includes helping the City Park Office of various cities in Indonesia provide advice and recommendations for landscaping development in their respective regions. Indonesia covers a wide area and has a high diversity. Each area has unique characteristics and must be handled individually, so that recommendations and development suggestions can not be given in a general form.

Besides the City Park Office, I have also been often asked to work cooperatively with the Ministry of Construction of the Republic of Indonesia, especially from LPJK (Lembaga Pengembangan Jasa Konstruksi/ Construction Services Development Board). Through this institution we have prepared many important documents of ethic code for the construction service in landscape construction work. World of construction services in Indonesia is derived from and protected by Law number 18 year 2000 (Undang-Undang no. 18/ 2000) about Construction Service.

By the law, it is stated the necessity to develop certified construction

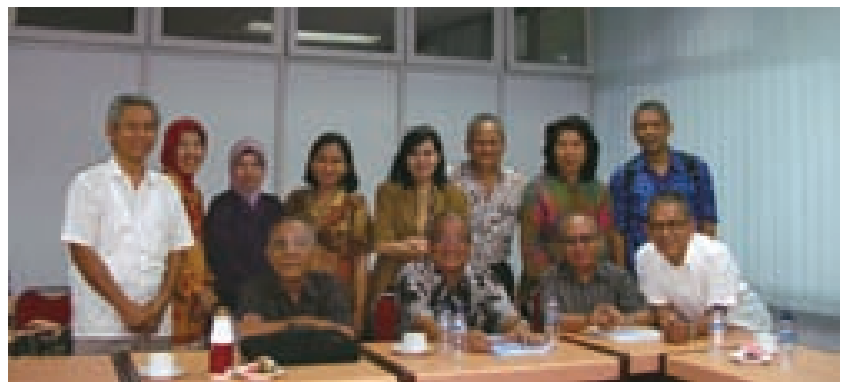

Figure 3. Contribution to Ministry of Construction of the Republic of Indonesia

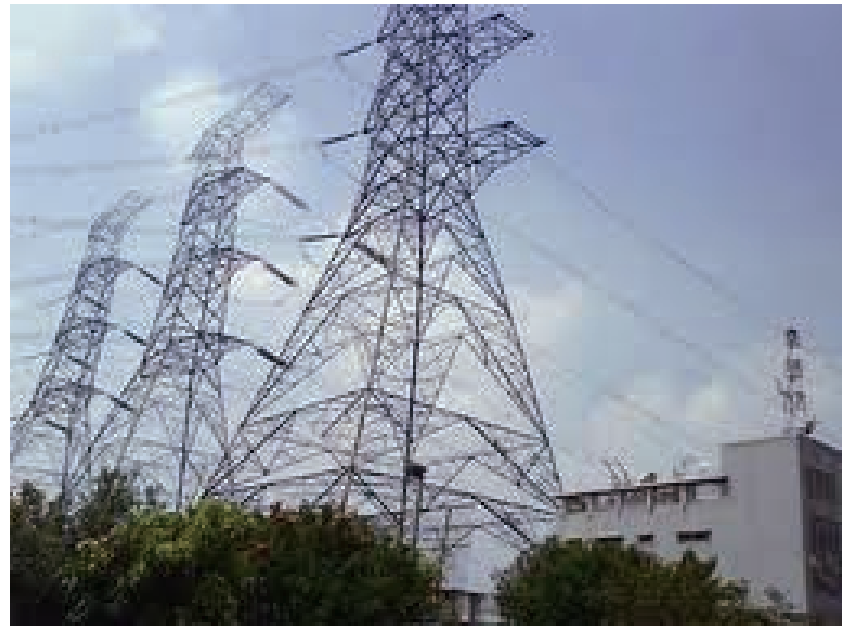

Figure 4. The extra high voltage line

experts. In 2003, LPJK accredited ISLA (Indonesian Society of Landscape Architects) to issue expertise certificates for its members. ISLA members who had been certified have a qualification as an expert in construction planning, execution and supervision of landscape construction work.

The Ministry of Environment is another office which often invites me to assist in the preparation of environmental impact assessments, because I am a member of national commission for national park impact assessment. This commission has a duty to direct and control the construction development that is spreading into the national park area. Usually in the national park we find obstacles to the development of public facilities like the extra high voltage air lines, where the line network splits the national park area. Therefore, it is necessary to carefully study the line network because it will have a great risk toward biota, habitat and ecosystem that exist within the national park.

\section{Role in educational development}

Below, I will describe some related activities in the field of educational development. Most of the time, I conduct educational activities because of my status as a faculty staff. But what I meant here is the other activity of extra- curricular field.

\section{AET-IPB}

Since 2004, I have been entrusted by the President of Bogor Agricultural University as a Chairman of Agro-Education Tourism Management Team. The activity's name is Agro-edu-tourism, abbreviated as AET of IPB. Activity of this tourism is essentially a new model and the only one conducted in Indonesia that empowers college faculty to provide educational services for the public.

The purpose of AET of IPB is to improve the image of agriculture education in Indonesia in general and IPB in particular. Since the eco- 




Figure 5. Elementary students enjoying AET program

nomic crisis that struck Indonesia around 1998, there has been a decrease in interest to study in the field of agriculture, resulting in a signif-

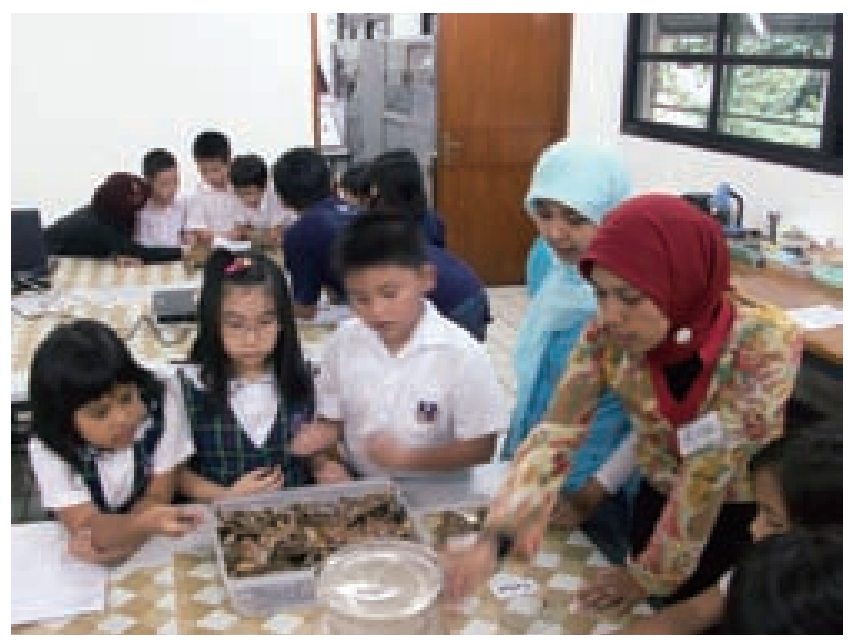

Figure 6. Students enjoying AET program at Insect Museum



Figure 7. Another student gets experience at Faculty of Husbandry icant impact and closing of some agricultural faculty in various places in Indonesia. This situation also occurred to IPB. In order to prevent this decrease of agricultural education image, IPB has been eagerly evaluating and changing its curriculum system, and performing various promotional activities. AET is one of strategic activity for IPB to promote, as well as to increase the interest for applicants.

The AET development concept is very simple, it uses the assets owned by IPB to provide service to the public through giving practical knowledge and technology. Of course, the community needs to know the secret of science and technology in agriculture in worldwide definition. The focus of the activity is to target students from kindergarten to high school. As a regional area, the target group is focused on schools located around Jabodetabek (Metropolitan and hinterland of Jakarta, Bogor, Depok, Tangerang and Bekasi). However, the AET welcomes the visiting of tourism education from schools outside the Jabodetabek.

IPB-AET activities have been supported by all the stakeholders of



Figure 8. Other students get experience on hydroponic culture at Greenhouse

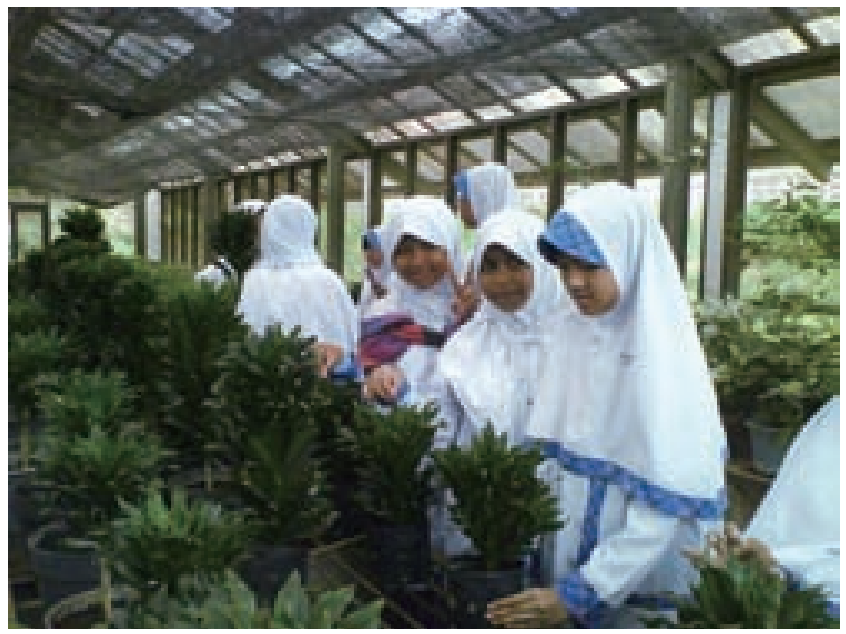

Figure 9. Students of High School Other students get experience on plant nursery 
agro-edu tourism on the campus of IPB, which has laboratories embedded in every department. Formerly, some attractions for tourism at department have not to be ready to become the potential object to sale for tourism activities, because not every department has a capability to advantage the opportunities. Herewith, the role of Management Team of IPB-AET is to support every department to explore the tourism attraction through the using of facilities that are available in each laboratory. The AET Management Team helps to formulate tourism program packages, and then sale to many school.

Many schools from kindergarten through high school are interested in the AET program. This is due to the fact that in every school there are subjects in the curriculum that require the students to participate in practical activities or fieldtrips. Some schools are already sufficiently equipped with facilities, but generally there is a limitation of practicum facilities in many schools, so the fieldtrip program is important to improve the understanding of the subject and is considered a priority. For example, in order to deepen the subjects of Biology and Environmental Science, the AET lets students see and practice at IPB, so that they will be interested and more easily understand the lesson material. In the visit to IPB, the students take a tour package associated with those lessons, for example by conducting visit to Insect Museum, Arboretum Faculty of Forestry, and study the animal life and poultry in the Faculty of Animal Husbandry.

Today, IPB-AET activity is well-known by many other universities in Indonesia, and some want to be supervised to develop a similar AET program at their owned universities. AET is very pleased to share its experience with other universities or colleges, because the main objective is to increase the interest of students to study agriculture. The more universities that run the AET program, the quicker the AET mission will be accomplished.

The Directorate General of Higher Education of the Ministry of



Figure 10. Integrated Plant Clinic Car as a mobile clinic owned by Faculty of Agriculture IPB
Higher Education has supported AET activity since 2010 by providing multi-year grant (until the year 2012) for the development of entrepreneurship at Institutions of higher education.

\section{Integrated Plant Clinic Car}

Integrated Plant Clinic Car, Faculty of Agriculture IPB is a tool to provide services to the public to perform analytical tasks in the field of agriculture, including aspects of soil fertility, agronomy and horticulture technique, plant health, and analysis of green open space and service to make landscaping design. This car is also equipped with tools for the socialization of agriculture, including for screening films at night. Thus, this facility is like a laboratory that is ready to serve anytime and anywhere.

Procurement of the Integrated Plant Clinic Car (IPCC) was in 2009, so that this year it has been running for two years. The procurement was sponsored by the Directorate General of Higher Education of The Ministry of National Education through a competitive grant with a program to increase the image of agricultural education at universities.

With the integrated plant clinic car the Faculty of Agriculture of IPB is expected by society to take the advantage in agriculture aspects as much as possible in the form of an agriculture advisory service with lower cost. Experts involved in the clinic car consist of several faculty staffs in the Faculty of Agriculture IPB, encompassing four departments.

IPCC is programmed to be ready to respond if called from the community. Most consultations would rarely involve all four departments. Sometimes activity is only about plant health problem, so that the more urgent issue is the readiness of the lecture team from the Department of Plant Protection and Department of Agronomy and Horticulture.

If there is a need for special consultation of Gardening Service concerning the design and garden health, the lecture team from Depart-



Figure 11. Integrated Plant Clinic viewed from the front 


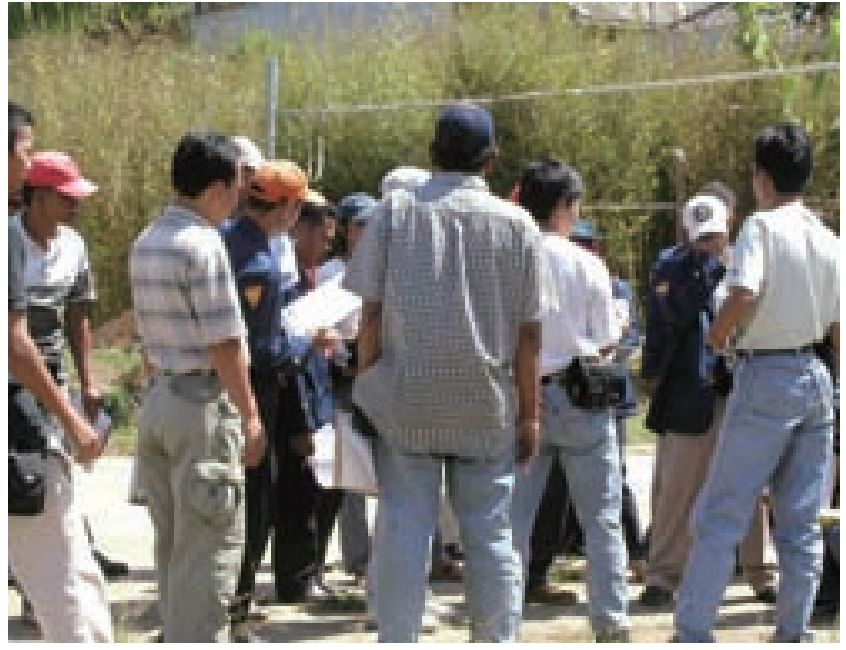

Figure 12. Activity at Professional Social Service at Rural Area

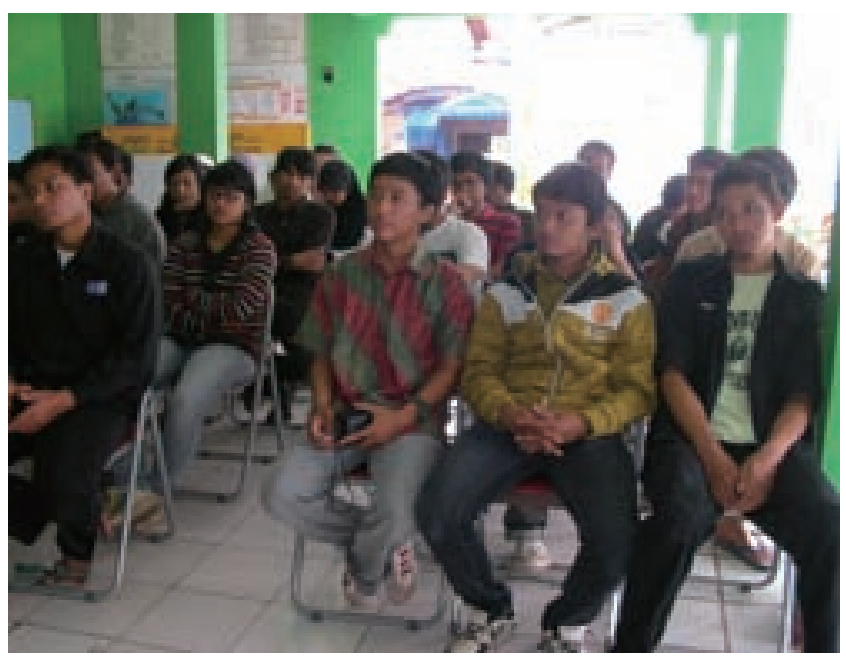

Figure 13. Activity at Professional Social Service at Rural Area by students at Faculty of Agriculture IPB

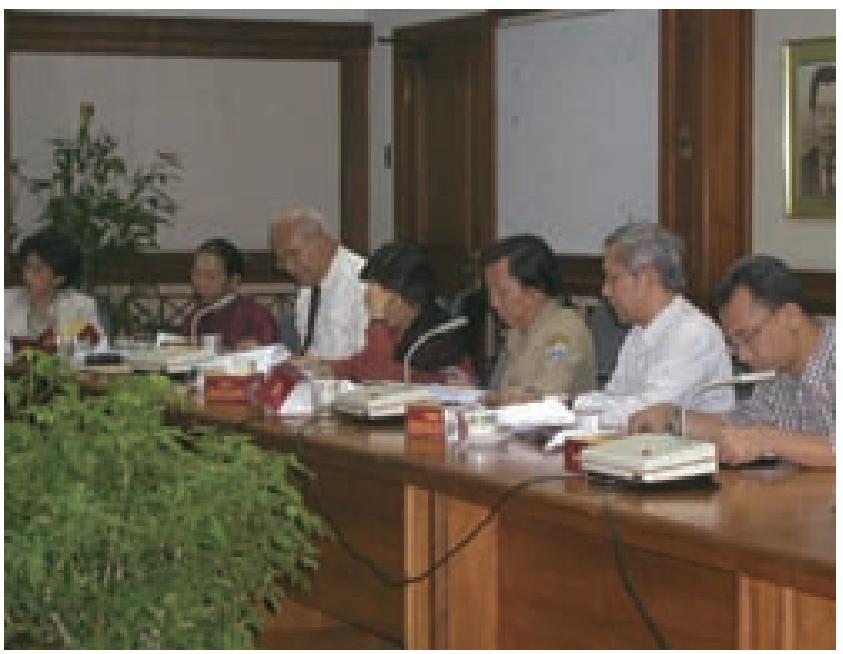

Figure 14. Activity for public consultation services at Jakarta Municipal Government



Figure 15. Neighborhood park participation at East Jakarta

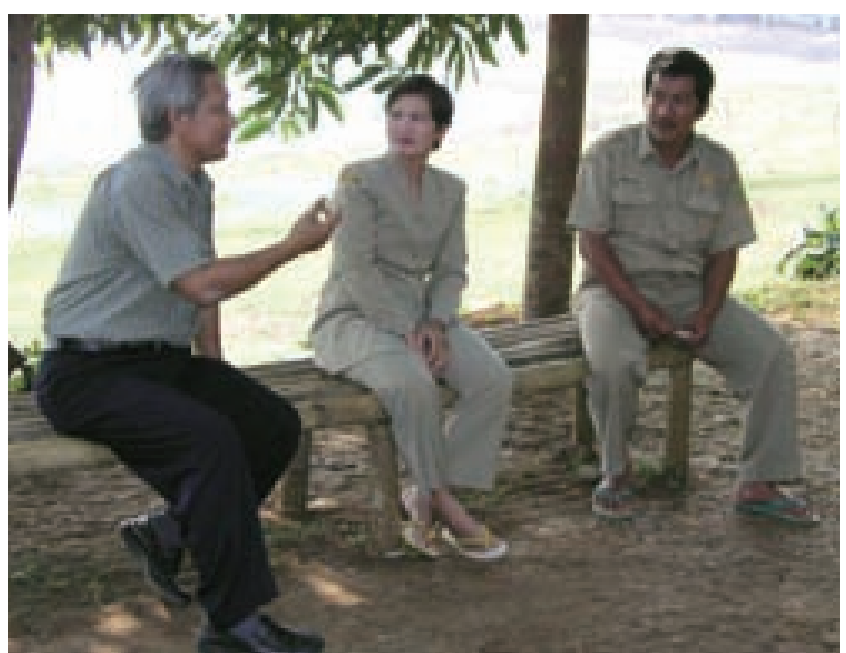

Figure 16. Encouraging the power from local government in manage water resource at Kuningan West Java

ment of Landscape Architecture and Department of Plant Protection is more preferred for readiness to serve. The service mechanism of using IPCC is set by Clinic Car Secretariat at Faculty of Agriculture, IPB. Specifically, I myself am involved in a lecture team that is responsible in the management service field of Landscape Architecture.

IPCC is also very useful in supporting KKP (Kuliah Kerja Profesi/ Professional Social Service Work). In this situation, IPCC provides service to many rural communities integrated with program of agricultural development at each rural area. Surely many local governments are very enthusiastic with the presence of IPCC in their respective regions.

\section{The role in profession development}

In the professional world of landscape architecture, I have some op- 


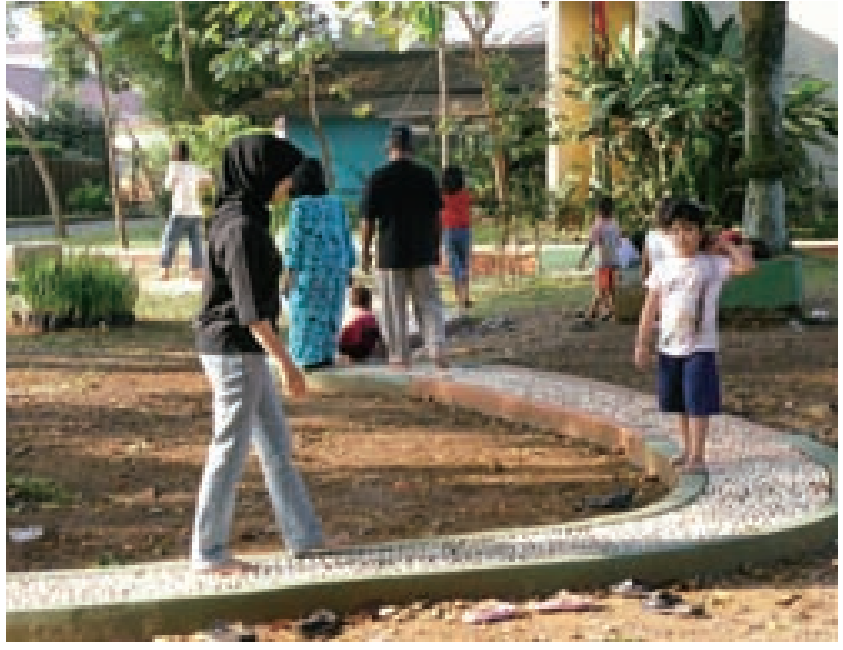

Figure 17. Encouraging the power from local community in manage and funding community park at Bogor City, West Java; People using their own community park

portunities to participate in public consultation and expertise certification.

\section{Public Consultation Service}

Some local governments ask for my help as an expert in planing for the development of parks and green open spaces. The most frequent request comes from the provincial government of DKI Jakarta. Of course there are also many requests as an expert from other local governments located outside of Java Island. Besides, I have been requested to supervise planning consultant agencies. In general, I am involved as an expert in planning and designing of various landscape works, including landscape master plan work and making DED (detailed engineering design). The duty as an expert in both local government and consultant agencies is not binding, but only under a contract agreement for completion of the job.

\section{Expertise Certification Service}

Since 2009, I have been assisting the National Executive Board of Indonesia Society of Landscape Architect (ISLA/ Ikatan Arsitek Lanskap Indonesia) and I have the duty as a Chairman of The Expertise Certification Board (Chairman of BSA/ Badan Sertifikasi Keahlian). BSA is an independent body that was established by the ISLA to provide expertise certificates for ISLA members. As cited above, ISLA has been accredited to issue certificates of expertise.

The Expertise Certification Board (BSA) domicile is in the national capital of Jakarta. An ISLA member who proposes the expertise certificate should fulfill the registration document through their respective local board. The Local Board is provincial-level administrators. BSA will conduct a verification test to evaluate documents and make any correc-

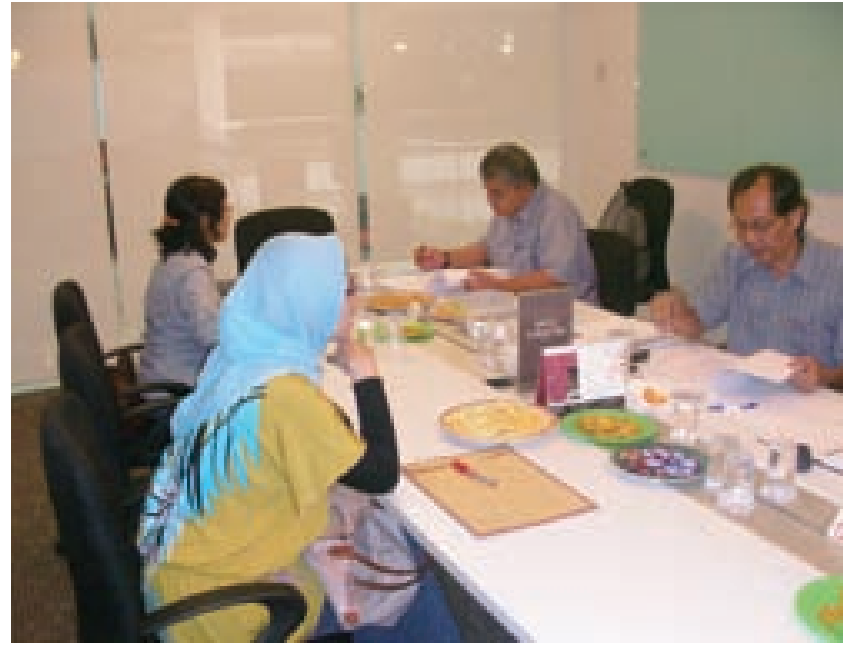

Figure 18. Process of expertise certification for the member of ISLA (Indonesian Society of Landscape Architects)

tion toward self-assessment by each applicant. In advance, BSA publishes expertise certificates to applicants who complete the requirements, and classifies them into categories of expertise provided. Experts who have already been certified are ranked into three levels, Young Expert, Middle Expert and Senior Expert. To achieve the higher expertise additional value of the landscape architectural work is required.

The Expertise certificate is needed to find construction service work in Indonesia. The certificate is even valid internationally. Someone who will work in the field of landscape architecture construction service abroad must submit their expertise certificate in Indonesia first. In Indonesia, these certificates must be owned by someone who will be involved in construction work, especially jobs that involve planning and or construction of public facilities and managed by central and local government. The period of validity of the certificate is 3 years, and must be extended before expiring. At the time of extending the valid period, the expert can increase their expertise rating, as long as satisfied with work values required.

In this regard, I myself am currently also involved in the SKKNI (Indonesian National Work Competence Standard) for Open Space Planner. Preparation of the SKKNI is conducted under the authority of Human Resources and Construction Development Agency, Ministry of Public Works of the Republic of Indonesia. Later, the standard for open space planner should be re-evaluated to raise its expert competency. So the above mentioned is a short brief on my experience and work in the area of environmental horticulture in my own country. I hope the vessel of communication between us currently can enrich my daily duty, both on campus and off campus. I would like to thank all of my teachers who helped and bring me toward very wide duties and responsibilities 
and gave a large benefit for the progress of my nation.

\section{References}

Agro-edu-tourism Management Team. (2010): Science, technology and art program for the campus innovation and creativity: The Development of Agro-edu-tourism at Bogor Agricultural University.

ECOTOURISMBIZ International Ecotourism Business Forum. (2007): “Ecotourism Economically and Socially Viable Tourism” at Bogor Botanical Garden.

Faculty of Agriculture, Bogor Agricultural University. (2009): Program Revitalisasi Pendidikan Pertanian untuk Membangun Kemandirian Bangsa (The Revitalization Program of Agriculture Education for Nation Independence Building).

Forum Pendidikan Arsitektur Lansekap Indonesia (Indonesian Landscape
Architecture Education Forum). (2009): Workshop Report on Coding of Landscape Architecture Education and Profession.

Sulistyantara, B. (2009) : Some problems faced in the developing green open spaces at Jakarta, Indonesia. Urban Green Tech, Organization for Landscape and Urban Greenery Technology Development, Japan no. 72 .

Sulistyantara, B., N. Nasrullah and Isdiyantoro. (2009) : Trees carbon storage estimation of green open space in East Jakarta Municipality using landsat imagery. Proceeding of Green City Symposium, Bogor Agricultural University.

Sulistyantara, B., I. W. Hidayat, Nasiruddin, and Hendrawan. (2009): Building the tree inventory application for city of East Jakarta. Proceeding of Green City Symposium, Bogor Agricultural University.

(Received 3 Feb. 2011; Accepted 1 Mar. 2011) 